\title{
STAGNANT OR GROWING: CAN MANAGEMENT SCIENCES EVOLVE BEYOND KNOWN BUSINESS CHALLENGES?
}

\author{
A Special Edition of Acta Commercii
}

Editors: Dr Geoff Goldman and Dr Carl Marnevick

Foreword

As global markets embark on some serious introspection after the global crisis of 2008, many business decision makers are asking "How did this happen?" What has become clear, however, is that we are stumbling from one business crisis to another. First it was corporate scandals such as Enron, Parmalat and Fidentia. Then came the financial crisis and the dire straits of, inter alia, Merrill Lynch, RBS, and Lehmann Brothers. Luckily, perhaps, it is not known what and when the next crisis will be. What is certain is that it will come. This begs the question: does business ever learn from what has gone before?

What corporate scandals and the economic crisis of 2008 have brought to the fore is that it is not "business as usual" any more. And along with that one can speculate as to the relevance of so called "academically sound" principles of business. In this, new business arena, "tried and tested" has suddenly become "flawed by complacency". In short, our theories (which have an obvious symbiotic relationship with practice) of what constitutes sound business and sound business practice, have failed us. Maybe it is time to look at those economies that have picked themselves out of despair, those economies that have faced seemingly insurmountable social, political and infrastructural challenges. Maybe the BRICS- type of economies are those that are setting the pace in the second decade of the $21^{\text {st }}$ century.

This thinking could be interpreted as confrontational and controversial; but is that not our very task as academics? If we as academics merely toe the line, follow the path of convention and act as opinion followers; are we making a contribution to new knowledge? The answer is a resounding "No". Imagine a world without the challenges on convention by Socrates, Descartes, Kant, Copernicus, Hegel, Newton, Nietzsche, Darwin, Marx, Einstein, Hubble and countless others. What a dull, boring place the world would be.

As an academic journal Acta Commercii, aims to do just that. We need to debate, question, challenge and explore. As Emmanuel Kant revealed, the world comes to us through the questions that we ask. We would like to encourage, develop and nurture a journal that promotes the seeking of answers to the right questions; rather than a platform that promotes seeking answers to the same old questions we have always asked. We need to challenge the questions before we can challenge how we need to answer them. 
This Special Edition of Acta Commercii is a collection of the five best papers from the University of Johannesburg Faculty of Management Conference held at Amanzingwe Lodge in Broederstroom, Gauteng, from 29 - 31 May 2011. The conference encouraged original work of scholarly quality from both the Positivist and Interpretive traditions. All competitive papers were subject to a strict double-blind peer review process based on the full paper, using the Acta Commercii review form as the basis of evaluation. The review panel was sufficiently represented from abroad..

As the editors, we would like to congratulate the authors who were invited to publish in this Special Edition. These papers represent the five Best Paper winners from the abovementioned conference. The authors were invited to publish these papers in this Special Edition of Acta Commercii..

\section{Dr. Geoff A Goldman \& Dr. Carl Marnewick Editors}

